\title{
Increase in Th17-associated CCL20 and decrease in Th2-associated CCL22 plasma chemokines in active ANCA-associated vasculitis
}

Per Eriksson, Carina Andersson, Petra Cassel, Sofia Nyström and Jan Ernerudh

\author{
Linköping University Post Print
}

\section{Tweet}

N.B.: When citing this work, cite the original article.

Original Publication:

Per Eriksson, Carina Andersson, Petra Cassel, Sofia Nyström and Jan Ernerudh, Increase in Th17-associated CCL20 and decrease in Th2-associated CCL22 plasma chemokines in active ANCA-associated vasculitis, 2015, Scandinavian Journal of Rheumatology, (44), 1, 80-83. http://dx.doi.org/10.3109/03009742.2014.952332

Copyright: Informa Healthcare http://informahealthcare.com/

Postprint available at: Linköping University Electronic Press http://urn.kb.se/resolve?urn=urn:nbn:se:liu:diva-114016 


\section{Increase in Th17-associated CCL20 and decrease in Th2-associated}

\section{CCL22 plasma chemokines in active ANCA-associated vasculitis}

letter

Per Eriksson MD, $\mathrm{PhD}^{\mathrm{a}}$, Carina Andersson biomedical scientist ${ }^{\mathrm{b}}$, Petra Cassel biomedical scientist $^{\mathrm{b}}$, Sofia Nyström MD, $\mathrm{PhD}^{\mathrm{b}}$, Jan Ernerudh MD, professor $^{\mathrm{b}}$

Affilations:

${ }^{\text {a }}$ Rheumatology, Department of Clinical and Experimental Medicine, Linköping University and Department of Rheumatology, County Council of Östergötland, Linköping, Sweden

${ }^{\mathrm{b}}$ Clinical Immunology, Department of Clinical and Experimental Medicine, Linköping University and Department of Clinical Immunology and Transfusion Medicine, County Council of Östergötland, Sweden

running title: Plasma chemokines in vasculitis

Reprints and correspondence to:

Per Eriksson

Dept of Rheumatology

University hospital

SE 58185 Linköping, Sweden

+46101030000 Fax +46101031844

per.eriksson@lio.se

Deviations in T helper (Th) subpopulations, including expansion of Th17 $(1,2)$, have been implicated in the pathogenesis of granulomatosis with polyangiitis (GPA) and microscopic 
polyangiitis (MPA) (ANCA-associated vasculitis). Th-associated cytokines occur at low concentrations in plasma, while chemokine responses commonly are 10- to 50-fold more intense than those of cytokines (3). Moreover, chemokines are strongly linked to different Thsubsets since they are induced by key cytokines (IFN- $\gamma$, IL-4/IL-13, IL-17) in order to recruit respective Th subset (4-8) and they have proven useful as markers of Th1, Th2 and Th17associated diseases $(3,4,9)$. In the present study we assessed chemokines and cytokines representative of Th1-, Th2-, and Th17-like immunity in patients with GPA or MPA.

Two separate cohorts of patients with GPA or MPA (10) were included (Table 1a and 1b). Cohort I was compared to 19 healthy controls (mean age 65 years, $60 \%$ men). After subsequent re-analyse of these samples they were added to 19 new controls (mean age 58 years, $37 \%$ men) and compared to cohort II. The study was approved by the regional ethics committee.

EDTA plasma were stored in $-70^{\circ} \mathrm{C}$. Milliplex Human MAP Cytokine/Chemokine Panel (Millipore, Billerica, MA, USA) was used to measure (lowest detection limit in brackets): Th1; $\operatorname{IFN}-\gamma(3.2 \mathrm{pg} / \mathrm{ml})$ and CXCL10 (16 pg/ml), Th2; IL-13 (3.2 pg/ml) and CCL22 (80 pg/ml), Th17; IL-17A, in the following termed IL-17 (1.6 pg/ml), IL-23 (p19/p40) (49 pg/ml), CCL20 (10 pg/ml) and CXCL1 (16 pg/ml). Due to low detectability IL-23 was only analysed in cohort I.

CXCL10-levels (Th1) were higher in remission than in controls in the larger cohort II, but not in cohort I (Figure 1a). Both cohorts showed lower levels of Th2-associated CCL22 in active vasculitis, both compared to controls and to patients in remission (Fig 1b). CCL20-levels (Th17) were increased in active vasculitis compared to controls in both cohorts and possibly also compared to patients in remission (tendency in cohort I, significant in cohort II) (Figure 
1c). CXCL1-levels (Th17) were higher in remission compared to controls in the larger cohort II, while this was not seen in cohort I (Figure 1d). All findings in cohort II were confirmed when all patients (both cohorts) were analysed together, and no new significant findings appeared.

In contrast to chemokines, cytokine levels representing Th1 (IFN- $\gamma$ ), Th2 (IL-13) and Th17 (IL17 and IL-23) did not differ between the groups. The detectability of cytokines varied (78\%, $44 \%, 90 \%, 39 \%$ of patient samples were above the detection level for IFN $\gamma$, IL-13, IL-17 and IL-23, respectively). Conversely, CXCL10, CCL22, CXCL1 were detectede in all samples, while CCL20 was detected in only $3 \%$ of controls, in $32 \%$ of remission, and in $58 \%$ of active diseases-samples (Chi-square $\mathrm{p}<0.001$ in both cohorts).

Disease activity (BVAS) correlated negatively with plasma levels of CCL22 in both cohorts (Spearman rank $\mathrm{r}=-0.618, \mathrm{p}=0.0001$ and $\mathrm{r}=-0.311, \mathrm{p}=0.006$, respectively), and positively with CCL20 in both cohorts $(r=0.362, p=0.038$ and $r=0.279, p=0.015$, respectively). Similar negative correlations to CCL22 and positive correlations to CCL20 were also found for plasma levels of CRP and prednisolone dose. Plasma creatinine and CXCL10 correlated weakly in cohort II $(\mathrm{r}=0.263, \mathrm{p}=0.022)$ but not in cohort I. No other correlations were found between disease-associated parameters and cytokines/chemokines.

Thus, by using two cohorts of patients, we demonstrated increased plasma levels of CCL20 and CXCL1 and decreased CCL22-levels, indicating a disbalance in Th-associated chemokines in ANCA-associated vasculitis. The increase in CCL20 and CXCL1 is in line with previous reports on increased Th17-associated activity $(1,2)$, here extended to involve chemokines as Th17-markers. The decrease in Th2-associated CCL22 is new and points to a dysbalance also 
in the Th1/Th2-axis. The main findings were consistent across the cohorts, although cohort I revealed fewer aberrations in the remission group, which is likely due to the smaller sample size and the pre-dominance of patients with long-standing remission.

Our study confirms that chemokines, in contrast to cytokines, are readily detected in plasma (3). The finding that deviations of Th17 and Th2-chemokines occurred or were most pronounced in active disease, as well as the associations with disease activity and CRP for both CCL20 and CCL22, indicate that these chemokines could be useful as biomarkers of disease activity. However, a longitudinal study design is needed to make any conclusions regarding the predictive value of chemokines in vasculitis. 


\section{References}

1. Abdulahad W, Stegeman C, Limburg P, Kallenberg C. Skewed distribution of Th17 lymphocytes in patients with Wegener's granulomatosis in remission. Arthritis Rheum 2008;58:2196-2205.

2. Nogueira E, Hamour S, Sawant D, Henderson S, Mansfield N, Chavele K-M, et al. Serum IL-17 and IL-23 levels and autoantigen-specificTh17 cells are elevated in patients with ANCAassociated vasculitis. Nephrol Dial Transplant 2010;25:2209-2217.

3. Hayglass KT. The quest for predictive immune biomarkers. Clin Exp Allergy 2011;41:16561659.

4. Abrahamsson TR, Sandberg Abelius M, Forsberg A, Björksten B, Jenmalm. A Th1/Th2associated chemokine imbalance during infancy in children developing eczema, wheeze and sensitization. Clin Exp Allergy 2011;41:1729-1739.

5. Annunziato F, Cosmi L, Santarlasci V, Maggi L, Liotta F, Mazzinghi B, et al. Phenotypic and functional features of human Th17 cells. J Exp Med 2007;204:1849-1861.

6. Hirota H, Yoshitomi H, Hashimoto M, Maeda S, Teradaira S, Sugimoto N, et al. Preferential recruitment of CCR6-expressing Th17 cells to inflamed joints via CCL20 in rheumatoid arthritis and its animal models. J Exp Med 2007;204:2803-2812. 
7. Ye P, Garvey PB, Zhang P, Nelson S, Bagby G, Summer WR, et al. 2001. Interleukin-17 and lung host defense against Klebsiella pneumoniae infection. Am J Respir Cell Mol Biol 2001;25:335-340.

8. Yamashita U, Kuroda E. Regulation of macrophage-derived chemokine (MDC, CCL22) production. Crit Rev Immunol 2002;22:105-114.

9. Henningsson AJ, Tjernberg I, Malmvall BE, Forsberg P, Ernerudh J. Indications of Th1 and Th17 responses in cerebrospinal fluid from patients with Lyme neuroborrelios: a large retrospective study. J Neuroinflammation 2011;8:36.

10. Jeanette J, Falk R, Andrassy K, Bacon P, Churg J, Gross W, et al. Nomenclature of systemic vasculitides. Proposal of an international consensus conference. Arthritis Rheum 1994;37:187-192. 
Figure 1. Median levels (inter-quartiles) of plasma CXCL10 (reflecting Th1, Fig 1a), CCL22 (reflecting Th2, Fig 1b), and Th17-associated CCL20 (Fig 1c), CXCL1 (Fig 1d), and IL17A (Fig 1e). The figures show the results from cohort I and cohort II subdivided into the groups of active vasculitis, remission, and controls. Differences between groups were first tested with Kruskal Wallis test and if $\mathrm{p}<0.05$ subsequently with Mann-Whitney’s test. Values below the detection limit were given a value of half the detection limit, corresponding to half the value of the lowest standard point. 
Table 1a. Clinical characteristics of patients in remission (cohort I: 2006-2007, cohort II: 20112013).

\begin{tabular}{|c|c|c|c|}
\hline & $\begin{array}{l}\text { Cohort I } \\
n=15\end{array}$ & $\begin{array}{l}\text { Cohort } 2 \\
n=64\end{array}$ & $\begin{array}{l}\text { Difference } \\
\text { cohort I and } \\
\text { cohort II } \\
\text { p-value** }\end{array}$ \\
\hline Men/women (\%) & $6 / 9(40 \% / 60 \%)$ & $28 / 36(44 \% / 56 \%)$ & NS \\
\hline Age, mean (range) & $71(36-85)$ & $63(20-90)$ & 0.030 \\
\hline GPA/MPA (\%) & $10 / 5(67 \% / 33 \%)$ & $35 / 29(55 / 45 \%)$ & NS \\
\hline $\begin{array}{l}\text { PR3-/MPO-/no ANCA /both } \\
(\%)\end{array}$ & $\begin{array}{l}10 / 3 / 1 / 1 \\
(67 \% / 20 \% / 6.5 \% / 6.5 \%)\end{array}$ & $\begin{array}{l}34 / 28 / 0 / 2 \\
(53 \% / 44 \% / 0 / 3 \%)\end{array}$ & NS \\
\hline $\begin{array}{l}\text { Disease duration, months } \\
\text { mean (range) }\end{array}$ & $109(15-238)$ & $83(0.9-252)$ & NS \\
\hline $\begin{array}{c}\text { Duration of remisson, months } \\
\text { mean (range) }\end{array}$ & $88(2-218)$ & $49(1-151)$ & 0.025 \\
\hline \multicolumn{4}{|l|}{ Organ involvement (ever): } \\
\hline kidney $(\%)$ & $6(40 \%)$ & $45(70 \%)$ & 0.027 \\
\hline lung $(\%)$ & $6(40 \%)$ & $27(42 \%)$ & NS \\
\hline $\mathrm{ENT}(\%)$ & $9(60 \%)$ & $33(52 \%)$ & NS \\
\hline peripheral nerves $(\%)$ & $5(33 \%)$ & $22(34 \%)$ & NS \\
\hline $\operatorname{skin}(\%)$ & $3(20 \%)$ & $13(20 \%)$ & NS \\
\hline joints $(\%)$ & $7(47 \%)$ & $30(47 \%)$ & NS \\
\hline Isolated ENT disease (\%) & $3(20 \%)$ & $5(8 \%)$ & NS \\
\hline Numbers at dialysis/tx* & 0 & $1 / 1$ & - \\
\hline $\begin{array}{l}\text { Plasma creatinine*, } \mu \mathrm{mol} / \mathrm{l} \\
\text { mean (range) }\end{array}$ & $120(84-190)$ & $131(44-590)$ & NS \\
\hline Plasma CRP*, mg/L (range) & $10(10-16)$ & $12(10-43)$ & NS \\
\hline \multicolumn{4}{|l|}{ Therapy at sampling: } \\
\hline $\begin{array}{c}\text { Prednisolone (mg/day) } \\
\text { mean (range) }\end{array}$ & $1.2(0-5)$ & $5.6(0-40)$ & 0.001 \\
\hline Methotrexate $(\%)$ & $2(13 \%)$ & $15(23 \%)$ & NS \\
\hline Azathioprine (\%) & 0 & $12(19 \%)$ & NS \\
\hline Mycophenolate (\%) & 0 & $8(13 \%)$ & NS \\
\hline $\begin{array}{l}\text { none of Mtx, Aza, Myc } \\
(\%)\end{array}$ & $13(87 \%)$ & $29(45 \%)$ & 0.004 \\
\hline \multicolumn{4}{|l|}{ Previous therapy: } \\
\hline $\begin{array}{c}\text { Cyclophosphamide, } \\
\text { patients }(\%)\end{array}$ & $13(87 \%)$ & $58(91 \%)$ & NS \\
\hline $\begin{array}{l}\text { months before sample, } \\
\text { mean (range) }\end{array}$ & $81(11-187)$ & $64(0.3-214)$ & NS \\
\hline $\begin{array}{l}\text { Rituximab, } \\
\text { patients }(\%)\end{array}$ & 0 & $27(42 \%)$ & 0.002 \\
\hline $\begin{array}{l}\text { months before sample, } \\
\text { mean (range) }\end{array}$ & - & $21(0.3-100)$ & - \\
\hline
\end{tabular}

*at time of blood sampling. **Mann Whitney or Chi-square tests. NS=non-significant $\mathrm{ENT}=$ Ear, nose, throat, GPA=Granulomatosis with polyangiitis, MPA=Microscopic polyangiitis. $\mathrm{BVAS}=0$ at remission by definition. PR3- and MPO-ANCA were analysed with capture enzyme immune assay (Wielisa, Euro-Diagnostica AB, Malmö, Sweden). 
Table 1b. Clinical characteristics of patients with active vasculitis (cohort I: 2006-2007, cohort II: 2011-2013).

\begin{tabular}{|c|c|c|c|}
\hline & $\begin{array}{l}\text { Cohort I } \\
\mathrm{n}=18\end{array}$ & $\begin{array}{l}\text { Cohort } 2 \\
n=12\end{array}$ & $\begin{array}{l}\text { Difference } \\
\text { cohort I and } \\
\text { cohort II } \\
\text { p-value** }\end{array}$ \\
\hline Men/women (\%) & $12 / 6(67 \% / 33 \%)$ & $8 / 4(67 \% / 33 \%)$ & NS \\
\hline Age, mean (range) & $64(25-83)$ & $57(19-77)$ & NS \\
\hline GPA/MPA $(\%)$ & $12 / 6(67 \% / 33 \%)$ & $6 / 6(50 \% / 50 \%)$ & NS \\
\hline $\begin{array}{l}\text { PR3-/MPO-/no ANCA/both } \\
(\%)\end{array}$ & $\begin{array}{l}13 / 5 / 0 / 0 \\
(72 \% / 28 \% / 0 / 0)\end{array}$ & $\begin{array}{l}8 / 4 / 0 / 0 \\
(67 \% / 33 \% / 0 / 0)\end{array}$ & NS \\
\hline New vasculitis/relapse $(\%)$ & $11 / 7(61 \% / 39 \%)$ & $10 / 2(83 \% / 17 \%)$ & NS \\
\hline \multicolumn{4}{|l|}{ Organ involvement (ever): } \\
\hline kidney $(\%)$ & $14(78 \%)$ & $9(75 \%)$ & NS \\
\hline lung (\%) & $5(28 \%)$ & $4(33 \%)$ & NS \\
\hline ENT $(\%)$ & $11(61 \%)$ & $5(42 \%)$ & NS \\
\hline peripheral nerves $(\%)$ & $5(28 \%)$ & $6(50 \%)$ & NS \\
\hline $\operatorname{skin}(\%)$ & $4(22 \%)$ & $1(8 \%)$ & NS \\
\hline joints $(\%)$ & $9(50 \%)$ & $4(33 \%)$ & NS \\
\hline Isolated ENT disease (\%) & $2(11 \%)$ & $1(8 \%)$ & NS \\
\hline Numbers at dialysis/tx* & 0 & 0 & - \\
\hline $\begin{array}{l}\text { Plasma creatinine*, } \\
\qquad \mu \mathrm{mol} / \mathrm{l} \text { (range) }\end{array}$ & $170(75-621)$ & $119(54-240)$ & NS \\
\hline Plasma CRP*, mg/L (range) & $49(10-197)$ & $45(10-237)$ & NS \\
\hline BVAS* mean (range) & $15(5-36)$ & $15(3-30)$ & NS \\
\hline \multicolumn{4}{|l|}{ Therapy at sampling: } \\
\hline $\begin{array}{r}\text { Prednisolone }>30 \mathrm{mg} / \text { day } \\
\text { previous to sampling } \\
\text { days, mean (range) }\end{array}$ & $4(0-18)$ & $4(0-16)$ & NS \\
\hline Methotrexate (\%) & $3(16.5 \%)$ & $2(17 \%)$ & NS \\
\hline Azathioprine $(\%)$ & $2(11 \%)$ & $1(8 \%)$ & NS \\
\hline Mycophenolate (\%) & $3(16.5 \%)$ & 0 & NS \\
\hline $\begin{array}{c}\text { none of Mtx, Aza, Myc } \\
(\%)\end{array}$ & $10(56 \%)$ & $9(75 \%)$ & NS \\
\hline \multicolumn{4}{|l|}{ Previous therapy: } \\
\hline $\begin{array}{c}\text { Cyclophosphamide } \\
\text { patients }(\%)\end{array}$ & $10(56 \%)$ & $2(17 \%)$ & 0.033 \\
\hline $\begin{array}{l}\text { months before sample, } \\
\text { mean (range) }\end{array}$ & $30(0.03-87)$ & $17(0.5-35)$ & NS \\
\hline $\begin{array}{l}\text { Rituximab } \\
\text { patients }(\%)\end{array}$ & $2(11 \%)$ & $3(25 \%)$ & NS \\
\hline $\begin{array}{l}\text { months before sample, } \\
\text { mean (range) }\end{array}$ & $35(17-53)$ & $0.03(0-0.07)$ & NS \\
\hline
\end{tabular}

$*$ at time of blood sampling. **Mann Whitney or Chi-square tests. NS=non-significant ENT=Ear, nose, throat, GPA=Granulomatosis with polyangiitis, MPA=Microscopic polyangiitis. PR3- and MPO-ANCA were analysed with capture enzyme immune assay (Wielisa, Euro-Diagnostica AB, Malmö, Sweden). 


\section{Acknowledgements}

We thank Linda Öjeteg and Marianne Petersson for blood sampling and Maria C Jenmalm for valuable input on the design of the study and interpretation of chemokine results. We also thank Karin Backteman, Christina Sandell and Maria Pettersson for help with the collection of samples. The study was funded by grants from the Ingrid Asp and Bröderna Karlsson foundations for medical research, the County Council of Östergötland, and Linköping University Hospital. 
Cohort I

Remission Active Control

$n=15 \quad n=18 \quad n=20$

a

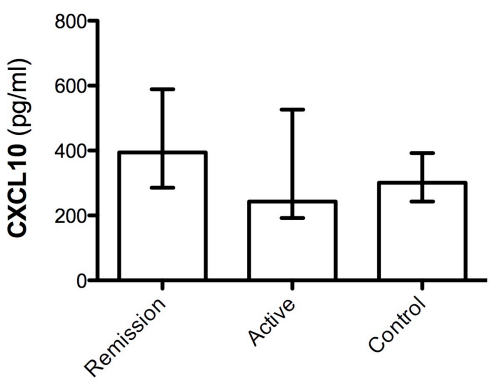

b

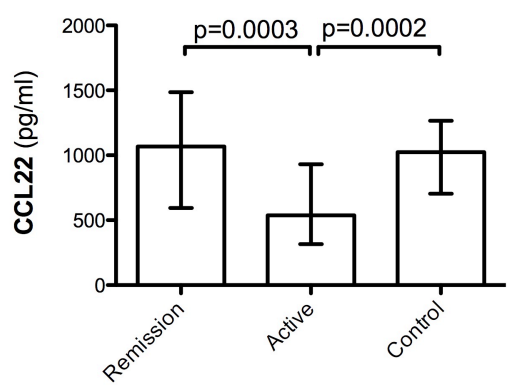

C

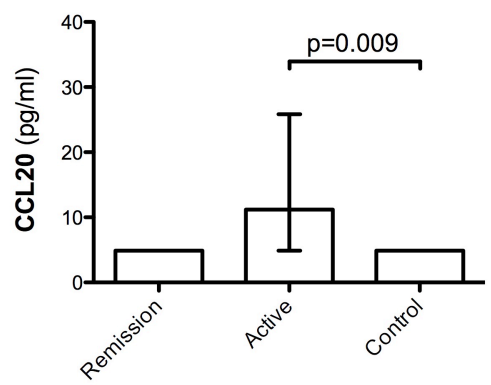

d

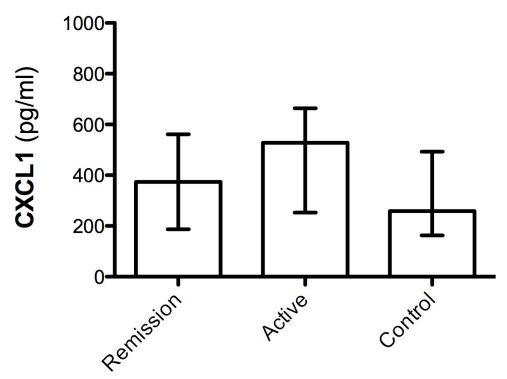

e

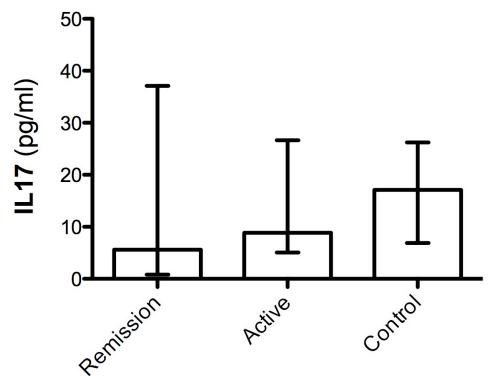

Cohort II

Remission Active Control
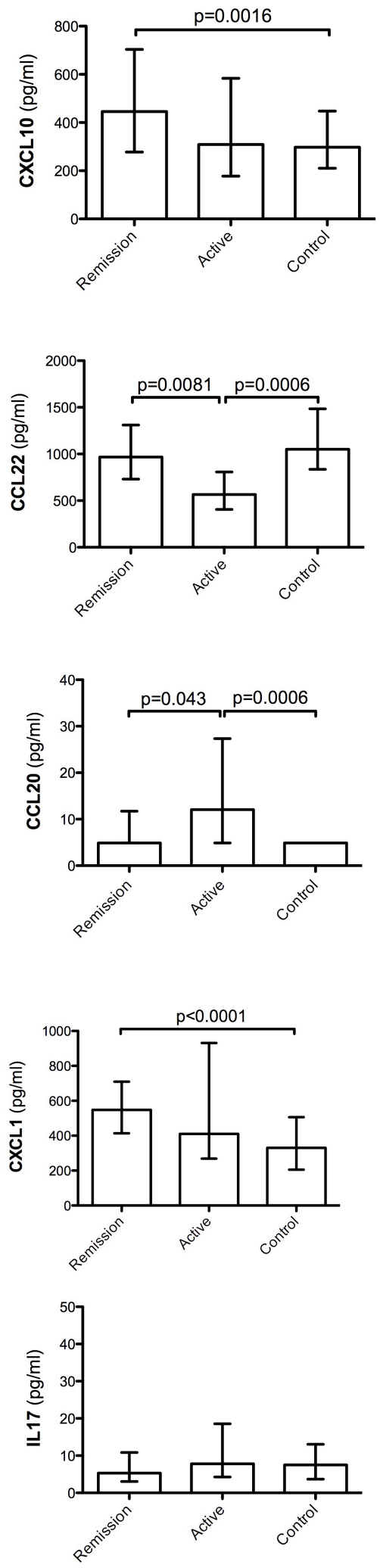